\title{
Growth Hormone (GH)-Releasing Peptide Stimulation of GH Release from Human Somatotroph Adenoma Cells: Interaction with GH-Releasing Hormone, Thyrotropin- Releasing Hormone, and Octreotide*
}

\author{
U. RENNER, S. BROCKMEIER, C. J. STRASBURGER, M. LANGE, J. SCHOPOHL, \\ O. A. MÜLLER, K. v. WERDER, AND G. K. STALLA \\ Max-Planck Institute of Psychiatry, Clinical Institute (U.R., S.B., M.L., G.K.S.); the Departments of \\ Medicine (C.J.S., J.S., O.A.M.) and Neurosurgery (M.L.), University of Munich; and the Medical \\ Department of Krankenanstalt Rotes Kreuz (O.A.M.), Munich; Schlosspark-Klinik, Free University of Berlin \\ (K.v.W.), Berlin, Germany
}

\begin{abstract}
The synthetic hexapeptide GH-releasing peptide (GHRP; His-DTrp-Ala-Trp-D-Phe-Lys- $\mathrm{NH}_{2}$ ) specifically stimulates $\mathrm{GH}$ secretion in humans in vivo and in animals in vitro and in vivo via a still unknown receptor and mechanism. To determine the effect of GHRP on human somatotroph cells in vitro, we stimulated cell cultures derived from 12 different human somatotroph adenomas with GHRP alone and in combination with GH-releasing hormone (GHRH), TRH, and the somatostatin analog octreotide. $\mathrm{GH}$ secretion of all 12 adenoma cultures could be stimulated with GHRP, whereas GHRH was active only in 6 adenoma cultures. In GHRH-responsive cell cultures, simultaneous application of GHRH and GHRP had an additive effect on GH secretion. TRH stimulated GH release in 4 of 7 adenoma cultures; in TRHresponsive cell cultures there was also an additive effect of GIIRP and TRH on GH secretion. In 5 of 9 adenoma cultures investigated,
\end{abstract}

octreotide inhibited basal GH secretion. In these cell cultures, GHRP. induced $\mathrm{GH}$ release was suppressed by octreotide. In 5 of 5 cases, the protein kinase-C inhibitor phloretin partly inhibited GHRP-stimulated $\mathrm{GH}$ release, but not basal $\mathrm{GH}$ secretion. In summary, $\mathrm{GH}$ secretion was stimulated by GHRP in all somatotroph adenomas investigated, indicating that its unknown receptor and signaling pathway are expressed more consistently in somatotroph adenoma cells than those for GHRH, TRH, and somatostatin. Our data give further evidence that GHRP-stimulated GH secretion is mediated by a receptor different from that for GHRH or TRH, respectively, and that protein kinase-C is involved in the signal transduction pathway. Because human somatotroph adenoma cell cultures respond differently to various neuropeptides (GHRH, TRH, somatostatin, and others), they provide a model for further investigation of the mechanism of action of GHRP-induced GH secretion. ( $J$ Clin Endocrinol Metab 78: 1090-1096, 1994)
G H-RELEASING peptide (GHRP), a synthetic hexapep$\exists$ tide (His-D-Trp-Ala-Trp-D-Phe-Lys- $\mathrm{NH}_{2}$ ) derived from enkephalins $(1,2)$, specifically stimulates $\mathrm{GH}$ secretion of somatotroph pituitary cells in animals both in vivo and in vitro $(3,4)$ as well as in normal humans $(5-7)$, short-statured children (8), and patients with acromegaly (9) in vivo. Because in humans GHRP is approximately as active as GH-releasing hormone (GHRH) and, moreover, can be administered orally, it may provide an alternate form of treatment of certain forms of GH deficiency $(5-7,10)$.

Previous studies demonstrated that GHRP does not stimulate $\mathrm{GH}$ release via the GHRH receptor $(11,12)$, the opiate receptors (13), or the receptor for pituitary adenylate cyclaseactivating polypeptide (14). Although the receptor for GHRP is not known, and the mechanism by which GHRP stimulates $\mathrm{GH}$ release is not well understood (15), part of the action of

Received May 5, 1993. Accepted January 21, 1993

Address all correspondence and requests for reprints to: Ulrich Renner, Ph.D., Max-Planck Institute of Psychiatry, Clinical Institute, Kraepelinstrasse 10, D-80804 Munich, Germany.

- Parts of this work were presented at the 36th Symposium of the German Society of Endocrinology, Erlangen, Germany, March 1992, and the 6th Meeting of the European Neuroendocrine Association, Lisboa, Portugal, 1993, and published as abstracts [Acta Endocrinol 126(Suppl 4):46, 1992; J Endocrinol Invest 16(Suppl 1):119, 1993].
GHRP seems to be mediated via protein kinase-C (PKC) (16). In this case, the action of GHRP is similar to that of phorbol 12-myristate 13-acetate. Previous studies investigating the interaction of GHRP with GHRH and somatostatin (SRIF) have demonstrated that SRIF suppresses GHRP-stimulated GH release $(3,11,15)$, and GHRP and GHRH stimulate $\mathrm{CH}$ secretion in a synergistic fashion $(5,15,16)$. GHRP-binding sites were detected not only in pituitary, but also in hypothalamic membrane fractions (17). Therefore, besides its action at the pituitary level, the possibility of a hypothalamic site of action of GHRP is still under discussion.

Somatotroph pituitary adenomas represent approximately $20 \%$ of the pituitary adenomas and cause acromegaly or gigantism due to $\mathrm{GH}$ hypersecretion under basal conditions (18). In normal somatotrophs, GH secretion is under control of the stimulatory action of hypothalamic GHRH and the inhibitory effect of its counterpart, SRIF (19). The disturbances in GH secretion of somatotroph adenoma cells, in addition to the quantitative abnormality of basal secretion, may involve qualitative abnormalities in the regulation of GH secretion, such as lack of stimulation by GHRH, paradoxical increase in GH after stimulation with TRH (18), and missing inhibition after administration of SRIF or SRIF analogs such as octreotide in a part of the adenomas $(20,21)$. 
The lack of GH stimulation by GHRH can be observed in about $30-40 \%$ of the somatotroph adenomas and was found to be due to the expression of the $g s p$ oncogene (22). This oncogene is derived from a single mutation in the $\alpha$-chain of the regulatory guanosine stimulatory G-protein $\left(\mathrm{G}_{s}\right)$ and leads to a constitutive activation of the adenylate cyclase system (23). As a result, cAMP production and associated GH secretion cannot be further stimulated by GHRH; therefore, $\mathrm{GH}$ secretion of this tumor type fails to respond to GHRH stimulation $(24,25)$.

The aim of the present study was to determine whether somatotroph adenomas in vitro respond differently to GHRP with respect to $\mathrm{GH}$ secretion, as has been found for GHRH, $\mathrm{TRH}$, and somatostatin. In addition, with somatotropic cell cultures, the effect of GHRP on GH release was studied comparatively with GHRH, TRH, and octreotide.

\section{Materials and Methods}

\section{Patients}

Pituitary adenoma tissue from 12 patients with somatotroph tumors (numbered consecutively ST 1 to ST 12) obtained at transsphenoidal surgery was studied. The presence of pituitary adenomas was confirmed by computerized tomography or magnetic resonance imaging. ST 2 was a recurrent adenoma from a patient who had undergone a first surgery $14 \mathrm{yr}$ previously. ST 4 was from a patient treated with octreotide (three doses; $100 \mu \mathrm{g}$ daily) over a period of 4 months before surgery. The clinical data of the patients are shown in Table 1.

\section{Cell culture}

Cell culture materials and reagents, except where stated, were obtained from Flow Laboratories (Meckenheim, Germany), Gibco Europe (Karlsruhe, Germany), Seromed (Berlin, Germany), Falcon (Heidelberg, Germany), or Nunc (Wiesbaden, Germany).

Human pituitary adenoma cell cultures were performed as described previously (26) with minor modifications. In brief, adenoma tissue was washed four times with preparation buffer $[137 \mathrm{mmol} / \mathrm{L} \mathrm{NaCl}, 5 \mathrm{mmol} /$ $\mathrm{L} \mathrm{KCl}, 0.7 \mathrm{mmol} / \mathrm{L} \mathrm{Na}_{2} \mathrm{HPO}_{4}, 15 \mathrm{mmol} / \mathrm{L}$ HEPES (pH 7.3), $10 \mathrm{mmol} / \mathrm{L}$ glucose, $2.5 \mathrm{mg} / \mathrm{L}$ amphotericin- $\mathrm{B}$, and $10^{5} \mathrm{U} / \mathrm{L}$ penicillin/streptomycin] and dissected into small pieces. The tissue fragments were mechanically and enzymatically dispersed in preparation buffer containing $1000 \mathrm{U} /$ $\mathrm{mL}$ collagenase (Worthington Biochemical Corp., Freehold, NJ), $4 \mathrm{~g} / \mathrm{L}$ BSA, $10 \mathrm{mg} / \mathrm{L}$ DNAase-II, $1 \mathrm{~g} / \mathrm{L}$ soybean trypsin inhibitor, and $2 \mathrm{~g} / \mathrm{L}$ hyaluronidase. Dispersed cells were centrifuged and resuspended in sterile culture medium (Dulbecco's Modified Eagle's Medium, pH 7.3) containing $10 \%$ fetal calf serum (FCS), $2.2 \mathrm{~g} / \mathrm{L} \mathrm{NaHCO}_{3}, 10 \mathrm{mmol} / \mathrm{L}$ HEPES, $2 \mathrm{mmol} / \mathrm{L}$ glutamine, $10 \mathrm{~mL} / \mathrm{L}$ nonessential amino acids, 10 $\mathrm{mL} / \mathrm{L}$ Minimum Essential Vitamins, $5 \mathrm{mg} / \mathrm{L}$ insulin, $5 \mathrm{mg} / \mathrm{L}$ transferrin, $2.5 \mathrm{mg} / \mathrm{L}$ amphotericin-B, $10^{5} \mathrm{U} / \mathrm{L}$ penicillin/streptomycin, $20 \mu \mathrm{g} / \mathrm{mL}$ sodium Selenit (Sigma Chemical Co., St. Louis, MO), and $30 \mathrm{pmol} / \mathrm{L} \mathrm{T}_{3}$ (Henning, Berlin, Germany). Between $22-40 \times 10^{6}$ cells with a viability of $92-98 \%$ (acridine orange-ethidium bromide staining) were isolated from pituitary tumors. The cells were diluted with culture medium and distributed to 24 -well tissue culture plates $\left(2 \times 10^{5}\right.$ cells/well in $1 \mathrm{~mL}$ medium). The cells were grown at $37 \mathrm{C}$ in an atmosphere of $5 \% \mathrm{CO}_{2}$. The dispersed cells attached to the culture dishes within the first $48 \mathrm{~h}$.

\section{Incubation of the cells with test substances}

Experiments were conducted on cells 2-3 days after plating. The growth medium was removed by aspiration, and the attached cells were washed several times with phosphate-buffered saline. For stimulation experiments, Dulbecco's Modified Eagle's Medium (pH 7.3) supplemented with $2.2 \mathrm{~g} / \mathrm{L} \mathrm{NaHCO}_{3}, 10 \mathrm{mmol} / \mathrm{L}$ HEPES, $2 \mathrm{mmol} / \mathrm{L}$ glutamine, $1 \mathrm{~g} / \mathrm{L} \mathrm{BSA}$, and $30 \mathrm{mg} / \mathrm{L}$ ascorbic acid (as an antioxidant) was used. GHRP (SmithKline Beecham, King of Prussia, PA), GHRH and TRH (both from Bachem, Bubendorf, Switzerland), the somatostatin analog octreotide (SMS 201-995; Sandoz, Basel, Switzerland), and the PKC inhibitor phloretin (Sigma Chemical Co., St. Louis, MO) $(16,27)$ were diluted in the same medium and added in the concentrations indicated. For studies in which combinations of the test substances were used, GHRP and GHRH were added to give concentrations of 1,10 , and 100 $\mathrm{nmol} / \mathrm{L}$ of each; GHRP and TRH or octreotide, respectively, were applied in concentrations of 10 or $100 \mathrm{nmol} / \mathrm{L}$ of each. The final volume was 1 $\mathrm{mL} /$ well in each case. After an incubation period of $4 \mathrm{~h}$, which was determined to be the optimal incubation time for all of the various test substances, the supernatants were removed and assayed for GH. Due to the limited numbers of cells obtained at some tumor cell preparations, not all studies could be performed in parallel with every somatotroph adenoma

\section{Determination of human (h) GH, PRL, and insulin-like growth factor-I}

$\mathrm{hGH}$ levels in cell culture supernatants were determined using a sensitive fluorescence immunometric assay, as described previously (28)

TABLE 1. Clinical characteristics of the 12 patients with somatotroph adenomas (ST 1 to ST 12)

\begin{tabular}{|c|c|c|c|c|c|c|c|c|c|c|c|}
\hline \multirow[b]{2}{*}{$\begin{array}{l}\text { Tumor } \\
\text { no. }\end{array}$} & \multirow[b]{2}{*}{$\begin{array}{l}\text { Age } \\
(\mathrm{yr})\end{array}$} & \multirow[b]{2}{*}{ Sex } & \multirow[b]{2}{*}{$\begin{array}{l}\text { Duration of } \\
\text { illness (yr) }\end{array}$} & \multirow[b]{2}{*}{$\begin{array}{l}\text { Adenoma } \\
\text { extension }\end{array}$} & \multicolumn{4}{|c|}{ Preoperative serum GH $(\mu \mathrm{g} / \mathrm{L})$} & \multirow[b]{2}{*}{$\begin{array}{l}\text { IGF-I } \\
(\mu \mathrm{g} / \mathrm{L})\end{array}$} & \multirow[b]{2}{*}{$\begin{array}{c}\text { PRL } \\
(\mu \mathrm{g} / \mathrm{L})\end{array}$} & \multirow[b]{2}{*}{$\begin{array}{l}\text { Pituitary } \\
\text { function }\end{array}$} \\
\hline & & & & & Basal & $\begin{array}{l}\text { After TRH } \\
\text { (200 } \mu \mathrm{g}, \\
\text { iv) }\end{array}$ & $\begin{array}{c}\text { After OGTT } \\
(100 \mathrm{~g} \\
\text { glucose })\end{array}$ & $\begin{array}{l}\text { After GHRH } \\
(100 \mu \mathrm{g}, \mathrm{iv})\end{array}$ & & & \\
\hline ST 1 & 58 & $\mathbf{F}$ & 4 & Intra/suprasellar & 59 & 113 & 123 & $\mathrm{NE}$ & 1507 & 13.7 & Normal \\
\hline ST 2 & 54 & $\mathrm{M}$ & $>16$ & Intra/parasellar & 91 & 123 & 98 & 114 & 1080 & 15.1 & Normal \\
\hline ST 3 & 60 & $\mathbf{F}$ & 5 & Intrasellar & 13 & 28 & 17 & NE & 1264 & 16.2 & $\mathrm{SH}$ \\
\hline ST 4 & 55 & $\mathrm{~F}$ & 3 & Intra/parasellar & 89 & 134 & 109 & $\mathrm{NE}$ & 561 & 41.8 & Normal \\
\hline ST 5 & 66 & $\mathrm{~F}$ & 3 & Intrasellar & 12 & 15 & 20 & $\mathrm{NE}$ & 1340 & 4.8 & Normal \\
\hline ST 6 & 66 & $\mathrm{~F}$ & 10 & Intra/parasellar & 10 & 27 & 15 & NE & 1495 & 11.9 & Normal \\
\hline ST 7 & 28 & $\mathrm{~F}$ & 5 & Parasellar & 13 & 14 & 8 & 17 & 964 & 6.0 & $\mathrm{SH}$ \\
\hline ST 8 & 34 & $F$ & $>10$ & Intrasellar & 15 & 48 & 13 & NE & 1343 & 11.3 & Normal \\
\hline ST 9 & 27 & $\mathrm{~F}$ & 4 & Intra/parasellar & 83 & 110 & 58 & 147 & 1146 & 7.2 & $\mathrm{SH}$ \\
\hline ST 10 & 55 & M & $i$ & Intrasellar & 36 & 94 & 31 & 137 & 2259 & 28.6 & Normal \\
\hline ST 11 & 41 & $\mathbf{M}$ & 5 & Intra/suprasellar & 37 & 62 & 33 & 56 & 2137 & 12.3 & Normal \\
\hline ST 12 & 59 & $F$ & 5 & Intra/parasellar & 46 & 53 & 41 & $\mathrm{NE}$ & 972 & 10.9 & Normal \\
\hline
\end{tabular}

Clinical characteristics of the patients from which the somatotroph adenomas were obtained. GH (normal, $<5 \mu \mathrm{g} / \mathrm{L}$ ) was determined with a fluorescence immunoassay, as described in Materials and Methods. IGF-I (normal range in adults, 180-480 $\mu \mathrm{g} / \mathrm{L}$ ) was determined using a kit from Nichols, and PRL (normal, 1-25 $\mu \mathrm{g} / \mathrm{L}$ ) was determined with a DELFIA kit. F, Female; M, male; NE, nonevaluable; OGTT, oral glucose tolerance test; $\mathrm{SH}$, secondary hypogonadism. 
with minor modifications. In brief, anti hCH monoclonal antibody clone $8 \mathrm{~B} 11$ was adsorbed to polystyrene microtiter plates ( $500 \mathrm{ng}$ antibody/ well) in $50 \mathrm{mmol} / \mathrm{L}$ phosphate buffer, $\mathrm{pH} 9.6$. After 16 -h incubation at $4 \mathrm{C}$, the plates were washed, and $50 \mu \mathrm{L}$ sample (diluted 1:20 to 1:50) or standard were added. Standards were prepared by serial dilution of recombinant hGH (Genotropin, Kabi, Stockholm, Sweden). Then, $30 \mathrm{ng}$ biotinylated anti-hGH monoclonal antibody clone 7F8 in $150 \mu \mathrm{L}$ assay buffer $[50 \mathrm{mmol} / \mathrm{L}$ Tris- $\mathrm{HCl}, 150 \mathrm{mmol} / \mathrm{L} \mathrm{NaCl}, 0.5 \% \mathrm{BSA}, 0.05 \%$ (wt) vol) bovine $\gamma$-globulin, $0.05 \%$ Tween- $40,0.05 \% \mathrm{NaN}_{3}$, and $20 \mu \mathrm{mol} / \mathrm{L}$ diethylenetriaminepentaacetic acid, $\mathrm{pH}$ 7.75] were added. After $2 \mathrm{~h}$ of incubation at room temperature, the plates were washed again, and 10 ng streptavidin-europium conjugate (Kabi-Pharmacia, Freiburg, Germany), dissolved in assay buffer, were added to each well (final volume, $200 \mu \mathrm{L}$ ). After an incubation period of $30 \mathrm{~min}$ at room temperature and a final wash step, $200 \mu \mathrm{L}$ europium fluorescence enhancement solution (Kabi-Pharmacia) were added, and the europium signal was measured in a time-resolved fluorometer (DELFIA, Wallacoy, Turku, Finland). The working range for cell culture samples was $0.12-100 \mathrm{ng} / \mathrm{mL}$, with an intraassay coefficient of variation of less than $10 \%$.

Serum GH levels were measured with the same method, using commercially available hGH standards prepared in ovine serum (Medgenix, Ratingen, Germany). The working range for serum samples is $0.18-110 \mathrm{ng} / \mathrm{mL}$.

Insulin-like growth factor-I serum levels were determined with a RIA kit (Nichols Institute, Bad Nauheim, Germany) after acid-ethanol extraction and cryoprecipitation. Serum PRL was measured with a DELFIA kit (Wallacoy). Both methods were conducted according to the instructions of the manufacturers.

\section{Statistics}

All experiments were performed at least in quadruplicate, and values are calculated as the mean $\pm S D$ and, with the exception of the data presented in Table 2, are expressed as a percentage of the control values. Statistics were determined by analysis of variance in combination with the Scheffe test. $P<0.05$ was considered significant.

\section{Results}

\section{Basal and stimulated GH secretion}

In vitro basal GH secretion varied from 107 (ST 2) to 438 (ST 12) ng GH/2 $\times 10^{5}$ cells. $4 \mathrm{~h}$ (Table 2 ). There was no correlation between basal GH secretion in vitro and plasma $\mathrm{GH}$ levels in vivo (compare with Table 1). As far as comparable, the responsiveness to GHRH and TRH was identical in vivo and in vitro, with the exception of ST 11, in which GHRH stimulated $\mathrm{GH}$ release in vivo but not in vitro (compare Tables 1 and 2).

GHRP (0.1-1000 nmol/L) stimulated GH release in a dosedependent manner in all 12 somatotroph adenoma cell cultures (a typical dose-response curve is shown in Fig. 1; see also Table 2 and Fig. 2). In all cases the stimulatory effects became significant at $1 \mathrm{nmol} / \mathrm{L}$ (range, $120 \pm 2 \%$ to $148 \pm$ $9 \%$ vs. basal secretion) and reached a plateau at $10 \mathrm{nmol} / \mathrm{L}$ (range, $126 \pm 4 \%$ to $184 \pm 12 \%$ ); no further significant stimulation of $\mathrm{GH}$ secretion could be observed with either 100 or $1000 \mathrm{nmol} / \mathrm{L}$ GHRP (range, $123 \pm 4 \%$ to $202 \pm 8 \%$ ).

GHRH $(0.1-1000 \mathrm{nmol} / \mathrm{L})$ stimulated $\mathrm{GH}$ secretion in six adenoma cell cultures dose dependently, but had no significant stimulatory effect in the six other cultures (for typical dose-response curve of a CHRH-responsive culture, see Fig. 1; see also Table 2 and Fig. 2). For GHRH-responsive cultures, stimulatory effects became significant at $1 \mathrm{nmol} / \mathrm{L}(127 \pm$ $1 \%$ and $134 \pm 4 \%$ ) in two cases (ST 1 and ST 10 ), and at 10
TABLE 2. In vitro characteristics of the somatotroph adenoma cell cultures

\begin{tabular}{cccccc}
\hline \multirow{2}{*}{$\begin{array}{c}\text { Tumor } \\
\text { no. }\end{array}$} & $\begin{array}{c}\text { Basal GH } \\
\text { secretion }\end{array}$ & \multicolumn{5}{c}{ Responsive in vitro to } \\
\cline { 2 - 6 } & & GHRP & GHRH & TRH & Octreotide \\
\hline ST 1 & 293 & + & + & ND & ND \\
ST 2 & 107 & + & - & ND & ND \\
ST 3 & 241 & + & - & ND & $-^{a}$ \\
ST 4 & 176 & + & - & ND & ND \\
ST 5 & 195 & + & - & ND & - \\
ST 6 & 392 & + & + & + & + \\
ST 7 & 117 & + & - & - & + \\
ST 8 & 208 & + & + & + & - \\
ST 9 & 156 & + & + & - & + \\
ST 10 & 354 & + & + & + & - \\
ST 11 & 144 & + & - & + & + \\
ST 12 & 438 & + & + & - & + \\
\hline
\end{tabular}

Characteristics of the 12 somatotroph adenoma cell cultures investigated with respect to basal GH secretion (nanograms of GH per $2 \times$ $10^{5}$ cells $/ 4 \mathrm{~h}$ ) and responsiveness to stimulation with GHRP, GHRH, $\mathrm{TRH}$, and octreotide. Cell cultures that responded to 1 or $10 \mathrm{nmol} / \mathrm{L}$ of the substances with a significant increase or decrease in $\mathrm{GH}$ secretion $(P<0.05)$ were considered to be responsive $(+)$. Cell cultures in which $\mathrm{GH}$ secretion could not be stimulated by excessively high concentrations $(100$ or $1000 \mathrm{nmol} / \mathrm{L})$ of the test substances were considered not responsive (-). ND, Not determined.

${ }^{a}$ Significant $(P<0.05$ vs. control) inhibition of GH secretion only at 1000 , but not at $100 \mathrm{nmol} / \mathrm{L}$ octreotide.

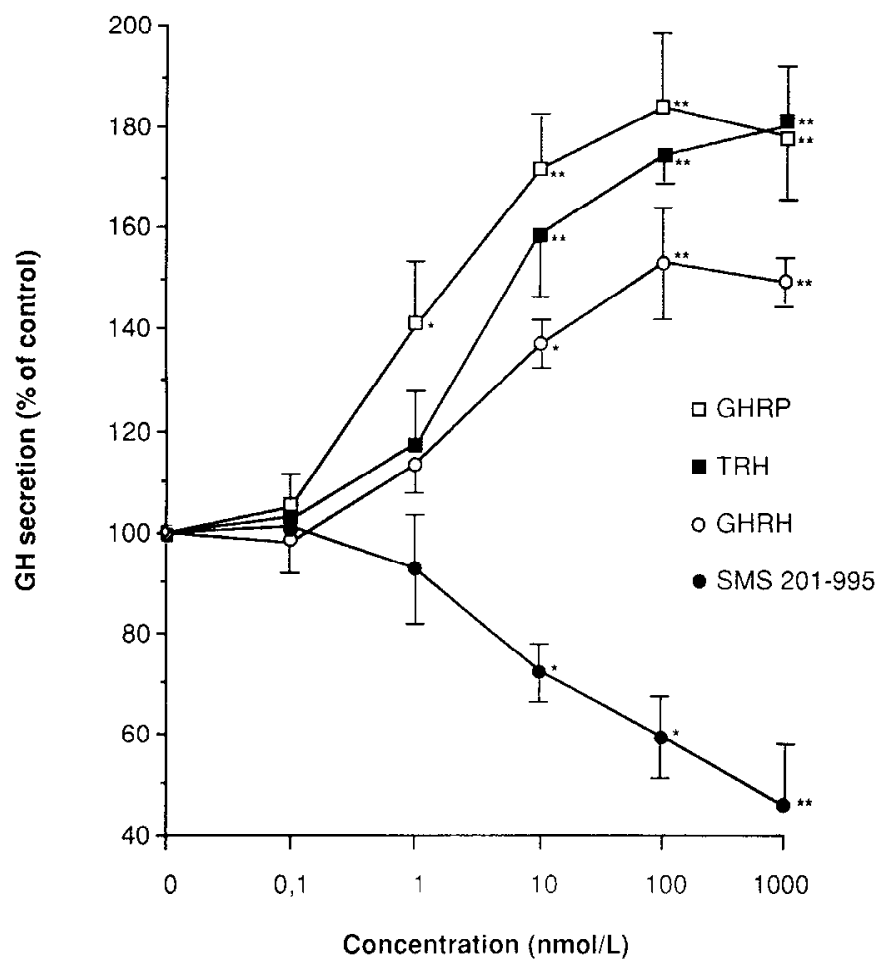

Fig. 1. Influence of increasing concentrations of GHRP, GHRH, TRH, and octreotide (SMS 201-995) on GH secretion of cultured cells of the somatotroph adenoma ST 6. In vitro, this adenoma responded to all of the substances tested, and significant stimulation of $\mathrm{GH}$ secretion could be observed after treatment with GHRP, GHRH, and TRH as well as significant inhibition of GH secretion after application of octreotide. $\star, P<0.05 ; \star \star, P<0.01$ [us. basal GH secretion (100\%)].

nmol/L (range, $124 \pm 3 \%$ to $135 \pm 7 \%$ ) in four cases (ST 6, 8,9 , and 12). Maximal stimulation was obtained with 100 


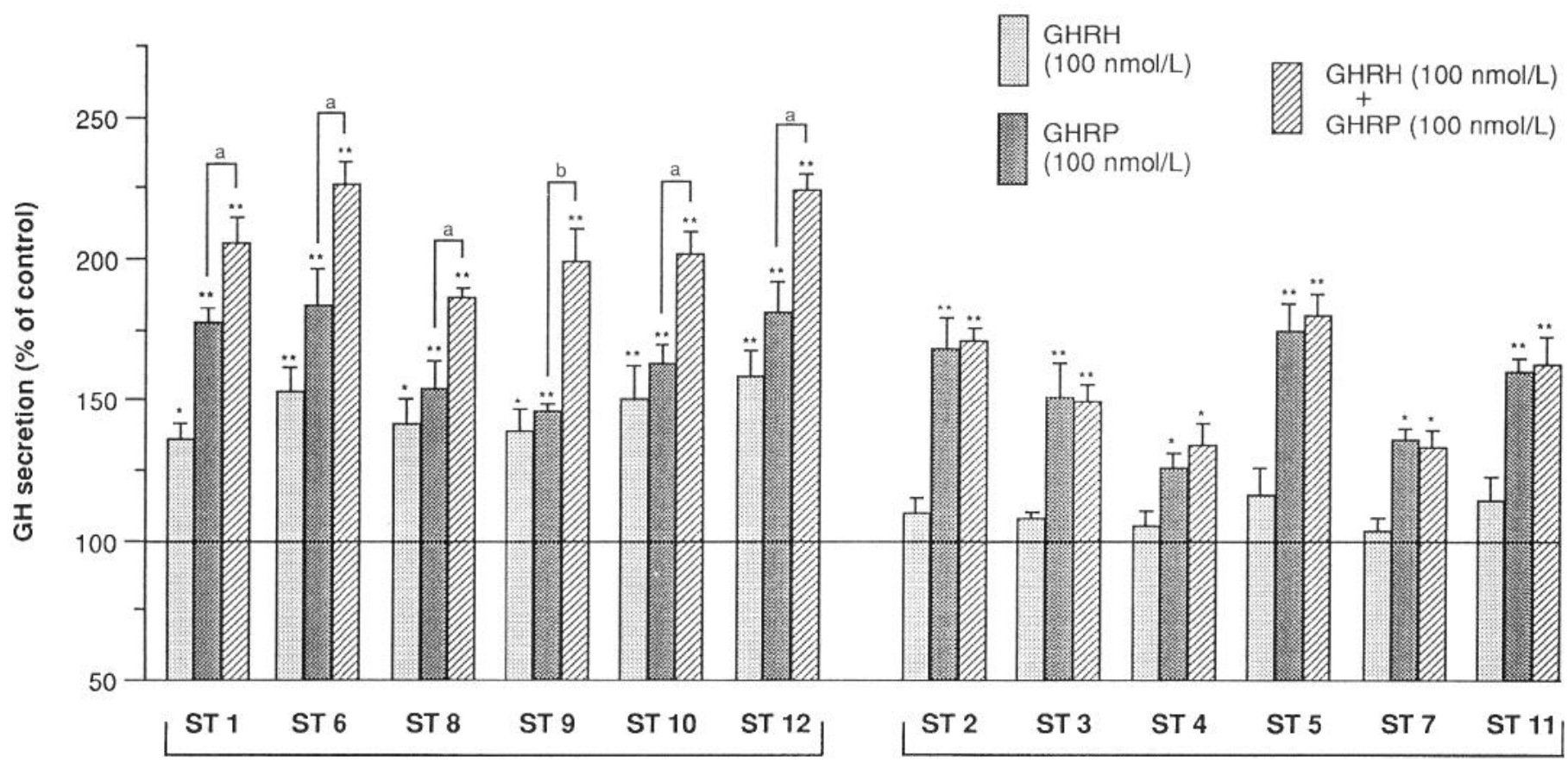

GHRH "responder"

GHRH "nonresponder"

FIG. 2. Comparison of the effects of GHRH $(100 \mathrm{nmol} / \mathrm{L})$ and GHRP (100 nmol/L), either alone or in combination, on the GH secretion of 12 individual adenoma cell cultures (ST 1 to ST 12). Basal secretion of the adenoma cultures was set at $100 \%$, and the results of the stimulation experiments are expressed as a percentage of the control value. $\star, P<0,05 ; \star \star, P<0,01$ (vs. control). In GHRH responders, simultaneous application of GHRH and GHRP led to a further significant increase in GH secretion $(\mathrm{a}, P<0.05 ; \mathrm{b}, P<0.01)$ compared to stimulation with GHRP alone.

nmol/L (range, $136 \pm 4 \%$ to $158 \pm 9 \%$ ). No further significant increase could be observed with $1000 \mathrm{nmol} / \mathrm{L}$ GHRH (range, $130 \pm 7 \%$ to $163 \pm 7 \%$ ).

The effect of TRH $(0.1-1000 \mathrm{nmol} / \mathrm{L})$ on $\mathrm{GH}$ secretion was tested in seven somatotroph adenoma cell cultures. In three of them, TRH had no significant effect, but stimulated $\mathrm{GH}$ release dose dependently in the other four cultures (Fig. 1; see also Table 2 and Fig. 3 ). In the TRH responders the stimulatory effect became significant at $10 \mathrm{nmol} / \mathrm{L}$ (range, $129 \pm 5 \%$ to $159 \pm 9 \%$ vs. basal secretion) and reached maximum values at $100 \mathrm{nmol} / \mathrm{L}$ (range, $138 \pm 7 \%$ to $174 \pm$ $4 \%$ ), with the exception of one case (ST 8 ) in which a further significant stimulatory effect of TRH was observed with 1000 $\mathrm{nmol} / \mathrm{L}(161 \pm 8 \%$ vs. $138 \pm 7 \%$ at $100 \mathrm{nmol} / \mathrm{L})$.

Although the use of 10 -fold increments was critical, we calculated the approximate $\mathrm{ED}_{50}$ values for GHRP, GHRH, and TRH for the individual somatotroph adenomas to obtain information about the relative $\mathrm{GH}$-stimulating potency of these substances. The $\mathrm{ED}_{50}$ for GHRP ranged from 1.1-3.4 $\mathrm{nmol} / \mathrm{L}$, the $\mathrm{ED}_{50}$ for GHRH (in GHRH responders) from
FIG. 3. Comparison of the effects of TRH $(100 \mathrm{nmol} / \mathrm{L})$ and GHRP (100 $\mathrm{nmol} / \mathrm{L}$ ), either alone or in combination, on the GH secretion of seven individual somatotroph adenoma cell cultures (ST 6 to ST 12). Results are expressed as a percentage of the control value $(100 \%=$ basal secretion). $\star, P<0.05 ; \star \star, P<$ 0.01 (us. control). In TRH responders, simultaneous application of TRH and GHRP significantly stimulated $\mathrm{GH}$ secretion (a, $P<0.05$; b, $P<0.01$ ) compared to stimulation with GHRP alone.

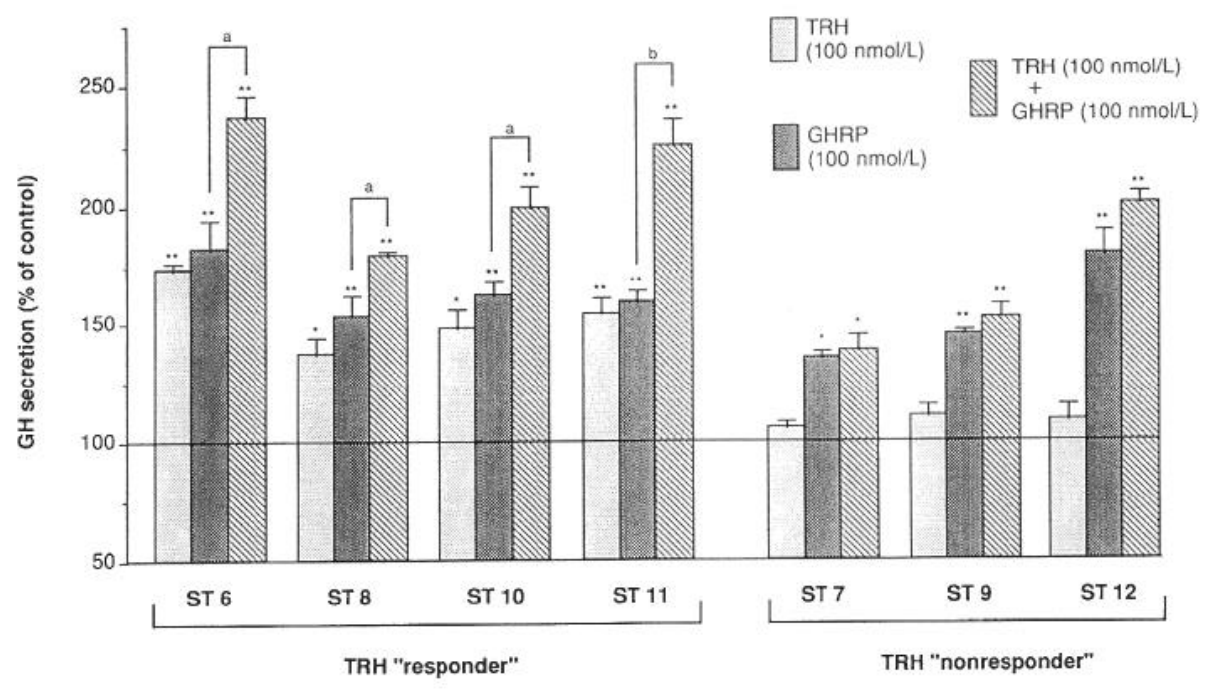


2.9-9.1 nmol/L, and the $\mathrm{ED}_{50}$ for TRH (in TRH responders) from $6.4-12.5 \mathrm{nmol} / \mathrm{L}$.

The influence of octreotide $(0.1-1000 \mathrm{nmol} / \mathrm{L})$ on basal $\mathrm{GH}$ release was studied with nine somatotroph adenoma cell cultures (Fig. 1; see also Table 2 and Fig. 4). Four adenoma cultures (ST 3, 5, 8, and 10) were considered to be not or only slightly responsive to octreotide, because $1-100 \mathrm{nmol} /$ L octreotide had no significant inhibitory effect on GH secretion. In only two cases (ST 3 and ST 8) was a slight, but significant, inhibition $(P<0,05)$ of basal GH release observed after application of $1000 \mathrm{nmol} / \mathrm{L}$ octreotide $(79 \pm 4 \%$ and 83 $\pm 1 \%$ of basal secretion). In contrast, five adenomas responded very well to octreotide. In one of these (ST 6), basal $\mathrm{GH}$ secretion was significantly inhibited by $1 \mathrm{nmol} / \mathrm{L}$ octreotide $(80 \pm 2 \%)$; $\mathrm{GH}$ was stimulated in all cases by $10 \mathrm{nmol} /$ $\mathrm{L}$ (range, $69 \pm 6 \%$ to $81 \pm 3 \%$ ). Basal GH release was further decreased by $100 \mathrm{nmol} / \mathrm{L}$ octreotide (range, $51 \pm 9 \%$ to 70 $\pm 4 \%$ ), but $1000 \mathrm{nmol} / \mathrm{L}$ had no further significant inhibitory effect (range, $48 \pm 4 \%$ to $65 \pm 8 \%$ ).

\section{Interaction of GHRH and GHRP on GH secretion}

In all somatotroph adenoma cultures the effects of GHRP and GHRH were investigated simultaneously (Fig. 2 summarizes the results for the stimulation with $100 \mathrm{nmol} / \mathrm{L}$ of each compound). In the six adenomas in which GH secretion could not be stimulated with GHRH, simultaneous application of GHRP and GHRH had the same stimulatory effect as GHRP alone. In the GHRH-responsive cell cultures, simultaneous stimulation with $100 \mathrm{nmol} / \mathrm{L}$ GHRP and GHRH had an additive effect on GH release (GHRP plus GHRH, $186 \pm$ $3 \%$ to $225 \pm 7 \%$; GHRP alone, $146 \pm 2 \%$ to $181 \pm 10 \%$ vs. basal secretion). This additive effect was also observed when combinations of the substances were used at lower concentrations ( 1 and $10 \mathrm{nmol} / \mathrm{L}$; data not shown).

\section{Interaction of TRH and GHRP on GH secretion}

In 7 of 12 adenoma cell cultures we studied the effects of GHRP and TRH on the GH release (Fig. 3 summarizes the effects for $100 \mu \mathrm{mol} / \mathrm{L}$ of each substance). In the $3 \mathrm{TRH}$ nonresponders, simultaneous application of GHRP and TRH resulted in the same stimulatory effect as application of GHRP alone. In TRH-responding somatotroph adenoma cultures, simultaneous application of $100 \mathrm{nmol} / \mathrm{L}$ GHRP and TRH had an additive effect on GH secretion (GHRP plus TRH, $181 \pm 2 \%$ to $239 \pm 9 \%$; GHRP alone, $154 \pm 9 \%$ to 184 $\pm 12 \%$ vs. basal secretion). The additive effect could also be seen, but was less pronounced, when $10 \mathrm{nmol} / \mathrm{L}$ TRH or GHRP were used (data not shown).

\section{Effect of octreotide on GHRP-stimulated GH secretion}

In 9 of 12 somatotroph adenoma cell cultures, the effect of the long-acting somatostatin analog octreotide (10 and $100 \mathrm{nmol} / \mathrm{L}$ ) on GHRP-stimulated GH release was investigated. In Fig. 4, the effects of $100 \mathrm{nmol} / \mathrm{L}$ octreotide on basal and GHRP-stimulated GH secretion are summarized (the effects of $10 \mathrm{nmol} / \mathrm{L}$ octreotide were similar, but less pronounced). In the 4 adenoma cell cultures that failed to respond or showed only a moderate response to octreotide, GHRP-induced GH secretion could not be significantly suppressed. In the adenoma cultures that responded to octreotide, however, significant decreases in GHRP-stimulated GH secretion could be observed after application of $100 \mathrm{nmol} / \mathrm{L}$ octreotide (GHRP alone, $136 \pm 3 \%$ to $184 \pm 12 \%$; GHRP plus octreotide, $75 \pm 8 \%$ to $106 \pm 4 \%$ vs. basal secretion).

\section{Influence of phloretin on GHRP-stimulated GH release}

In 5 of 12 cases (ST 8 to ST 12), the effects of phloretin (10 and $100 \mu \mathrm{mol} / \mathrm{L}$ ), an inhibitor of PKC, on basal and GHRP-stimulated GH release were investigated (Table 3). Phloretin had no cytotoxic effect on the cells, as demonstrated by viability staining using ethidium bromide and acridine orange. In all cases, even the high concentration of phloretin had no significant inhibitory effect on basal GH secretion (range, $91 \pm 8 \%$ to $98 \pm 6 \%$ vs. basal secretion). GHRP-stimulated GH secretion was significantly inhibited
FIG. 4. Effect of $100 \mathrm{nmol} / \mathrm{L}$ octreotide (SMS 201-995) on basal and GHRP (100 $\mathrm{nmol} / \mathrm{L})$-stimulated $\mathrm{GH}$ secretion of nine individual somatotroph adenoma cell cultures (ST 3 and ST 5 to ST 12). Basal GH secretion was set at $100 \%$, and results are expressed as a percentage of the control value. $\star, P<0.05 ; \star \star, P<$ 0.01 (vs. control). In cell cultures in which basal GH secretion could be significantly suppressed by octreotide, GHRP-stimulated GH secretion was also inhibited significantly (a, $P<0.01$; b, $P<0.001)$.

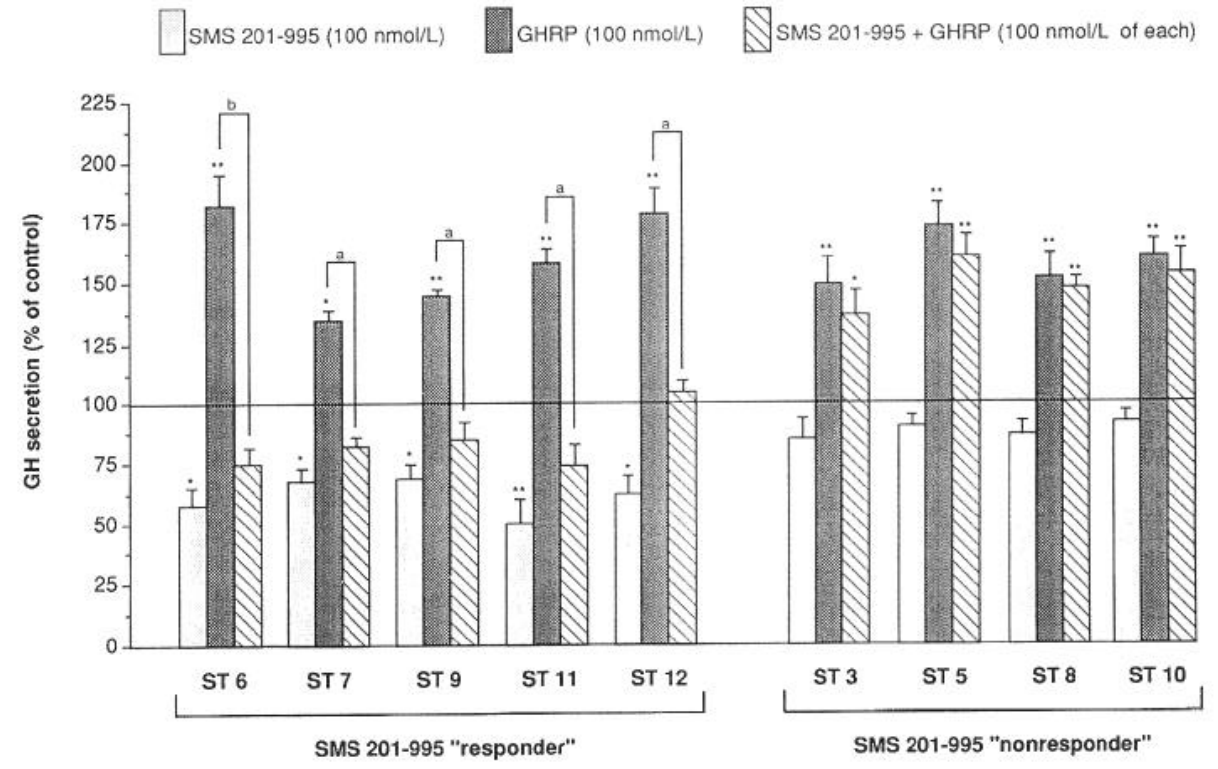


TABLE 3. Effect of phloretin on GHRP-stimulated GH secretion

\begin{tabular}{lrrrrr}
\hline \multicolumn{1}{c}{ Tumor no. } & ST 8 & ST 9 & ST 10 & ST 11 \\
\hline Basal & $100 \pm 7$ & $100 \pm 4$ & $100 \pm 5$ & $100 \pm 5$ & $100 \pm 7$ \\
$10 \mu \mathrm{mol} / \mathrm{L}$ phloretin & $94 \pm 3$ & $96 \pm 5$ & $100 \pm 3$ & $102 \pm 3$ & $94 \pm 5$ \\
$100 \mu \mathrm{mol} / \mathrm{L}$ phloretin & $92+6$ & $96 \pm 1$ & $97 \pm 3$ & $98 \pm 6$ & $91 \pm 8$ \\
& & & $163 \pm 6$ & $160 \pm 5$ & $181 \pm 10$ \\
100 nmol/L GHRP & $154 \pm 9$ & $146 \pm 2$ & $138 \pm 1^{a}$ & $133 \pm 4^{a}$ & $169 \pm 10$ \\
GHRP + 10 $\mu \mathrm{mol} / \mathrm{L}$ phloretin & $143 \pm 6$ & $137 \pm 7$ & $129 \pm 4^{a}$ & $119 \pm 1^{c}$ & $145 \pm 1^{a}$ \\
\hline
\end{tabular}

The effect of the PK-C inhibitor phloretin was investigated on both basal and GHRP $(100 \mathrm{nmol} / \mathrm{L})$-stimulated GH secretion of five individual somatotroph adenoma cell cultures. Each value represents the mean \pm SD of quadruplicate determinations and is expressed as a percentage of the control value (basal secretion). Significance was determined $v$ s. GH stimulation with $100 \mathrm{nmol} / \mathrm{L}$ GHRP.

${ }^{a} P<0.01$.

${ }^{b} P<0.05$.

$P<0.001$.

by $10 \mu \mathrm{mol} / \mathrm{L}$ phloretin in 2 of 5 cases and in all cases by $100 \mu \mathrm{mol} / \mathrm{L}$ phloretin. With the latter concentration, the maximum stimulatory effect of GHRP was reduced by $50-$ $60 \%$.

\section{Discussion}

The abnormal regulation of GII secretion in somatotroph adenoma cells involves basal GH hypersecretion and, in some of the adenomas, missing response to GHRH, paradoxical response to TRH, and missing inhibition response to somatostatin or its analogs $(18-21)$. Here we report that in vitro, GHRP stimulated GH secretion in all 12 somatotroph adenoma cell cultures investigated, whereas GHRH stimulated GH release in only 6 of 12 cases and TRH increased $\mathrm{GH}$ secretion in 4 of 7 cases. Our data confirm the results of a recent in vivo study in which it was shown that GHRP stimulated GH secretion in all 11 patients with acromegaly investigated (9). Our observation that GHRP was active in GHRH and TRH nonresponders confirms previous studies that GHRP acts through a receptor and a mechanism on GH secretion distinct from those of GHRH and TRH. This was further supported by our observation that the combined stimulation with GHRP and either GHRH or TRH had an additive effect on GH secretion, even in concentrations at which each of the substances alone had its maximal effect $(5-7,11)$.

Comparing the $\mathrm{ED}_{50}$ values of GHRP and GHRH for GHRH-responsive somatotroph adenoma cultures, GHRP is even more potent than GHRH in stimulating GH secretion. This is in agreement with in vivo findings, where it has been demonstrated that in most patients with acromegaly GHRP was more effective than GHRH in stimulating $\mathrm{GH}$ release (9). Previous studies have also shown that, in general, GHRP is nearly as potent as GHRH in stimulating GH secretion in humans, whereas GHRP is about 100 -fold less active than GHRH in rats (3-5). There is still no explanation for this phenomenon; human somatotroph adenoma cell cultures could provide a model for further studies on this topic.

In GHRH nonresponders, the missing effect of GHRH on $\mathrm{GH}$ secretion has been correlated with the expression of the gsp oncogene $(22,23)$. The expression of this oncogene leads to a constitutive activation of the adenylate cyclase system, and because GHRH mediates GH secretion via this second messenger system, the GH secretion is not or is only poorly stimulated by GHRH $(24,25)$. However, because the correlation between $g s p$ expression and GHRH nonresponsiveness is not $100 \%$, and exceptions were found $(24,25)$, we cannot be sure that all of our GHRH nonresponders are gsp positive. On the other hand, because about $40 \%$ of the somatotroph adenomas express the $g s p$ oncogene, by extrapolation, it would seem that GHRP is able to stimulate GH secretion in both $g s p$-negative and $g s p$-positive adenoma cells.

The mechanism of the paradoxical response of GH secretion to TRH stimulation observed in some somatotroph adenomas is not yet completely understood, but there is evidence that the TRH receptor is expressed in TRH responders, and the phosphoinositol pathway and PKC may be involved $(29,30)$. It is known from studies in rats that GHRP-stimulated GH secretion is also in part mediated via PKC (16). We could confirm this by the observation that in five somatotroph adenoma cultures investigated, the PKC inhibitor phloretin inhibited GHRP-stimulated GH secretion. On the other hand, we could show that GHRP and TRH in TRHresponsive adenoma cultures exerted an additive effect on $\mathrm{GH}$ secretion even at maximal stimulatory concentrations of each alone. Therefore, although the stimulation of $\mathrm{GH}$ by GHRP and TRH may share a common intermediate substance, namely PKC, the availability of PKC does not seem to be the rate-limiting step in the combined action of TRH and GHRP on GH secretion.

GH hypersecretion in acromegaly can often be reduced by medical treatment with somatostatin analogs, like the longacting analog octreotide. On the other hand, in some cases $\mathrm{GH}$ secretion is not influenced by octreotide $(18,19,21)$. The different responses of the somatotroph adenomas to somatostatin analogs have recently been recognized to be associated with the different expression of various somatostatin receptor subtypes that differ in their affinity to somatostatin or somatostatin analogs (21). Thus, tumors that do not respond to octreotide do not express the appropriate receptor. In our study, basal GH secretion of five of nine somatotroph adenoma cell cultures could be inhibited by octreotide. In these responders, GHRP-stimulated GH secretion was also suppressed significantly by octreotide. In contrast, octreotide had no inhibitory effect on GHRP-induced GH release in 
those adenoma cultures in which it was not able to suppress basal GH secretion. Therefore, independent from its mechanism, GHRP-stimulated GH secretion seems to be under the control of somatostatin, as was also shown in rats $(3,11$, 15 ), and can be inhibited in somatotroph adenoma cells that respond to octreotide.

In summary, GHRP was able to stimulate $\mathrm{GH}$ secretion dose dependently in all 12 human somatotroph adenoma cell cultures investigated. Thus, the expression of both the still unidentified receptor of GHRP and its unknown signaling pathway seems to be more consistent in somatotroph adenomas than in those for GHRH, TRH, and somatostatin, in which marked variations in different somatotroph adenoma subtypes with respect to stimulation or inhibition of GH secretion are observed. The action of GHRP is different from that of GHRH and TRH, but can be blocked by octreotide in octreotide-responsive adenomas. Although we could confirm the participation of PKC in GHRP-stimulated GH secretion, much more work is necessary to identify the mechanism of action of GHRP and to characterize its receptor.

\section{Acknowledgments}

We wish to thank Rosa Buric, Karin Lechner, Sabine Löbel, Johanna Stalla, Barbara Glöckner, and Katja Schriever for excellent technical assistance, and Dr. Christopher Newton for reviewing the manuscript for English usage.

\section{References}

1. Momany FA, Bowers CY, Reynolds GA, Chang D, Hong A, Newlander K. 1981 Design, synthesis, and biological activity of peptides which release growth hormone in vitro. Endocrinology. 108:31-39.

2. Momany FA, Bowers CY, Reynolds GA, Hong A, Newlander K. 1984 Conformational energy studies and in vitro and in vivo activity data on growth hormone releasing peptides. Endocrinology. 114:1531-1536.

3. Bowers CY, Momany FA, Reynolds GA, Hong A. 1984 On the in vitro and in vivo activity of a new synthetic hexapeptide that acts on the pituitary to specifically release growth hormone. Endocrinology. 114:1537-1545.

4. Sartor O, Bowers CY, Reynolds GA, Momany FA. 1985 Variables determining the growth hormone response of His-D-Trp-Ala-TrpD-Phe-Lys- $\mathrm{NH}_{2}$ in the rat. Endocrinology. 117:1441-1447.

5. Bowers CY, Reynolds GA, Durham D, Barrera CM, Pezzoli SS, Thorner MO. 1990 Growth hormone (GH)-releasing peptide stimulates $\mathrm{GH}$ release in normal man and acts synergistically with $\mathrm{GH}$ releasing hormone. J Clin Endocrinol Metab. 70:975-982.

6. Robinson BM, Friberg RD, Bowers CY, Barkan AL. 1992 Acute growth hormone $(\mathrm{GH})$ response to $\mathrm{GH}$-releasing hexapeptide in humans is independent of endogenous GH-releasing hormone. J Clin Endocrinol Metab. 75:1121-1124

7. Penalva A, Carballo A, Pombo M, Casanueva FF, Dieguez $\mathbf{C}$. 1993 Effect of growth hormone (GH)-releasing hormone (GHRH), atropine, pyridostigmine, or hypoglycemia on GHRP-6-induced GH secretion in man. J Clin Endocrinol Metab. 76:168-171.

8. Bowers CY, Alster DK, Frentz JM. 1992 The growth hormonereleasing activity of a synthetic hexapeptide in normal men and short statured children after oral administration. J Clin Endocrinol Metab. 74:292-298.

9. Alster DK, Bowers CY, Jaffe CA, Ho PJ, Barkan AL. 1993 The growth hormone $(\mathrm{GH})$ response to $\mathrm{GH}$-releasing peptide (His-DTrpAla-Trp-DPhe-Lys- $\mathrm{NH}_{2}$ ), GH-releasing hormone, and thyrotropinreleasing hormone in acromegaly. J Clin Endocrinol Metab. 77:842-
845 .

10. Walker RF, Codd EE, Barone FC, Nelson AH, Goodwin T, Campbell SA. 1990 Oral activity of the growth hormone releasing peptide His-D-Trp-Ala-Trp-D-Phe-Lys-NH2 in rats, dogs, and monkeys. Life Sci. 47:29-36.

11. Blake AD, Smith RG. 1991 Desensitization studies using perifused rat pituitary cells show that growth hormone-releasing hormone and His-D-Trp-Ala-Trp-D-Phe-Lys- $\mathrm{NH}_{2}$ stimulate growth hormone release through distinct receptor sites. J Endocrinol. 129:11-19.

12. Bowers CY, Sartor AO, Reynolds GA, Badger TM. 1991 On the actions of the growth hormone-releasing hexapeptide, GHRP. Endocrinology. 128:2027-2035.

13. Codd EE, Yellin T, Walker RF. 1988 Binding of growth hormonereleasing hormones and enkephalin-derived growth hormone-releasing peptides to mu and delta opiod receptors in forebrain of rat. Neuropharmacology. 27:1019-1025.

14. Goth MI, Lyons CE, Canny BJ, Thorner MO. 1992 Pituitary adenylate cyclase activating polypeptide, growth hormone (GH)releasing peptide, and $\mathrm{GH}$-releasing hormone stimulate $\mathrm{GH}$ release through distinct piluitary receptors. Endocrinology. 130:939-944.

15. Cheng K, Chan WWS, Barreto A Jr, Convey EM, Smith RG. 1989 The synergistic effects of His-D-Trp-Ala-Trp-D-Phe-Lys- $\mathrm{NH}_{2}$ on growth hormone $(\mathrm{GH})$-releasing factor-stimulated $\mathrm{GH}$ release and intracellular adenosine $3^{\prime}, 5^{\prime}$-monophosphat accumulation in rat primary pituitary cell culture. Endocrinology. 124:2791-2798.

16. Cheng K, Chan WWS, Butler B, Barreto Jr A, Smith RG. 1991 Evidence for a role of protein kinase-C in His-D-Trp-Ala-Trp-D-PheLys- $\mathrm{NH}_{2}$-induced growth hormone release from rat primary pituitary cells. Endocrinology. 129:3337-3342.

17. Codd EE, Shu AYL, Walker RF. 1989 Binding of a growth hormone releasing hexapeptide to specific hypothalamic and pituitary binding sites. Neuropharmacology. 28:1139-1144.

18. Melmed S, Braunstein GD, Horvath E, Ezrin C, Kovacs K. 1983 Pathophysiology of acromegaly. Endocr Rev. 4:271-290.

19. Reichlin S. 1987 Control of GH secretion: an overview. In: Lüdecke DK, Tolis G (eds) Growth hormone, growth factors, and acromegaly. New York: Raven Press; 1-11.

20. Frohman LA. 1991 Therapeutic options in acromegaly. J Clin Endocrinol Metab. 72:1175-1181.

21. Lamberts SWJ, Krenning EP, Reubi J-C. 1991 The role of somatostatin and its analogs in the diagnosis and treatment of tumors. Endocr Rev, 12:450-482.

22. Vallar L, Spada A, Giannattasio G. 1987 Altered $G_{s}$ and adenylate cyclase activity in human $\mathrm{GH}$-secreting pituitary adenomas. Nature. 330:566-568.

23. Landis CA, Masters SB, Spada A, Pace AM, Bourne HR, Vallar L. 1989 GTPase inhibiting mutations activate the a chain of $G_{s}$ and stimulate adenylyl cyclase in human pituitary tumours. Nature. 340:692-696.

24. Landis CA, Harsh G, Lyons J, Davis RL, McCormick F, Bourne HR. 1990 Clinical characteristics of acromegalic patients whose pituitary tumors contain mutant $\mathrm{G}_{\mathrm{s}}$ protein. J Clin Endocrinol Metab. 71:1416-1420.

25. Spada A, A rosio M, Bochicchio D, et al. 1990 Clinical, biochemical, and morphological correlates in patients bearing growth hormonesecreting pituitary tumors without or with somatic mutation in the alpha-chain of the stimulatory regulatory protein of adenylyl cyclase $\left(\mathrm{G}_{\mathrm{s}}\right)$. J Clin Endocrinol Metab. 71:1421-1426.

26. Arzt E, Stelzer G, Renner U, Lange M, Müller OA, Stalla GK. 1992 Interleukin-2 and interleukin-2 receptor expression in human corticotrophic adenoma and murine pituitary cell cultures. I Clin Invest. 90:1944-1951

27. Richardson SB, Twente S, Newman CB. Growth hormone secretion in vitro and in vivo is inhibited by flavonoids [Abstract]. Proc of the 69th Annual Meet of The Endocrine Soc. 1987;107.

28. Strasburger CJ, Barnard G, Toldo L, et al. 1989 Somatotropin as measured by a two-site time-resolved immunofluorometric assay. Clin Chem. 35:913-917.

29. Martin FTJ. 1983 Thyrotropin-releasing hormone rapidly activates the phosphodiester hydrolysis of polyphosphoinositides in $\mathrm{CH}_{3}$ pituitary cells. J Biol Chem. 238:14816-14822.

30. Le Dafniet M, Garnier P, Bression D, Brandi AM, Racadot J, Peillon F. 1985 Correlative studies between the presence of thyrotropin-releasing hormone (TRH) receptors and the in vitro stimulation of growth hormone secretion in $\mathrm{GH}$-secreting adenomas. Horm Metab Res. 17:476-479. 